\section{MODEL \\ PENGEMBANGAN \\ PETUGAS LAPANGAN KELUARGA BERENGANA}

Maya Yusnita, S.E., M.Si., CRA., CRP. adalah Dosen Jurusan Manajemen Fakultas Ekonomi Universitas Bangka Belitung (UBB), kelahiran Palembang. Gelar Sarjana Ekonomi diperoleh dari Fakultas Ekonomi dan Bisnis Universitas Lampung pada Tahun 2008. Gelar Magister Sains diraihnya dari Universitas Sriwijaya pada Tahun 2012. Penulis terlibat aktif dalam penelitian, pengabdian kepada masyarakat, menulis jurnal, serta berpartisipasi aktif dalam mengikuti berbagai seminar, workshop dan pelatihan. Kontak: 085669919279 dan email: mayayusnitaubb@gmail.com.

Duwi Agustina, S.E., M.Sc., CSRS., CSP., CSRA. adalah Dosen Jurusan Akuntansi Fakultas Ekonomi Universitas Bangka Belitung (UBB), kelahiran Lampung. Gelar Sarjana Ekonomi diperoleh dari Fakultas Ekonomi Universitas Muhammadiyah Yogyakarta. Gelar Magister Science (2010) diraihnya dari Universitas Gadjah Mada Yogyakarta. Aktif terlibat dalam penelitian, menulis diberbagai jurnal, serta aktif dalam mengikuti berbagai seminar. Kontak: 081367949381 dan email: duwiagustina7@gmail.com.
MODEL PENGEMBANGAN PETUGAS LAPANGAN KELUARGA BERENCANA

$\longrightarrow$
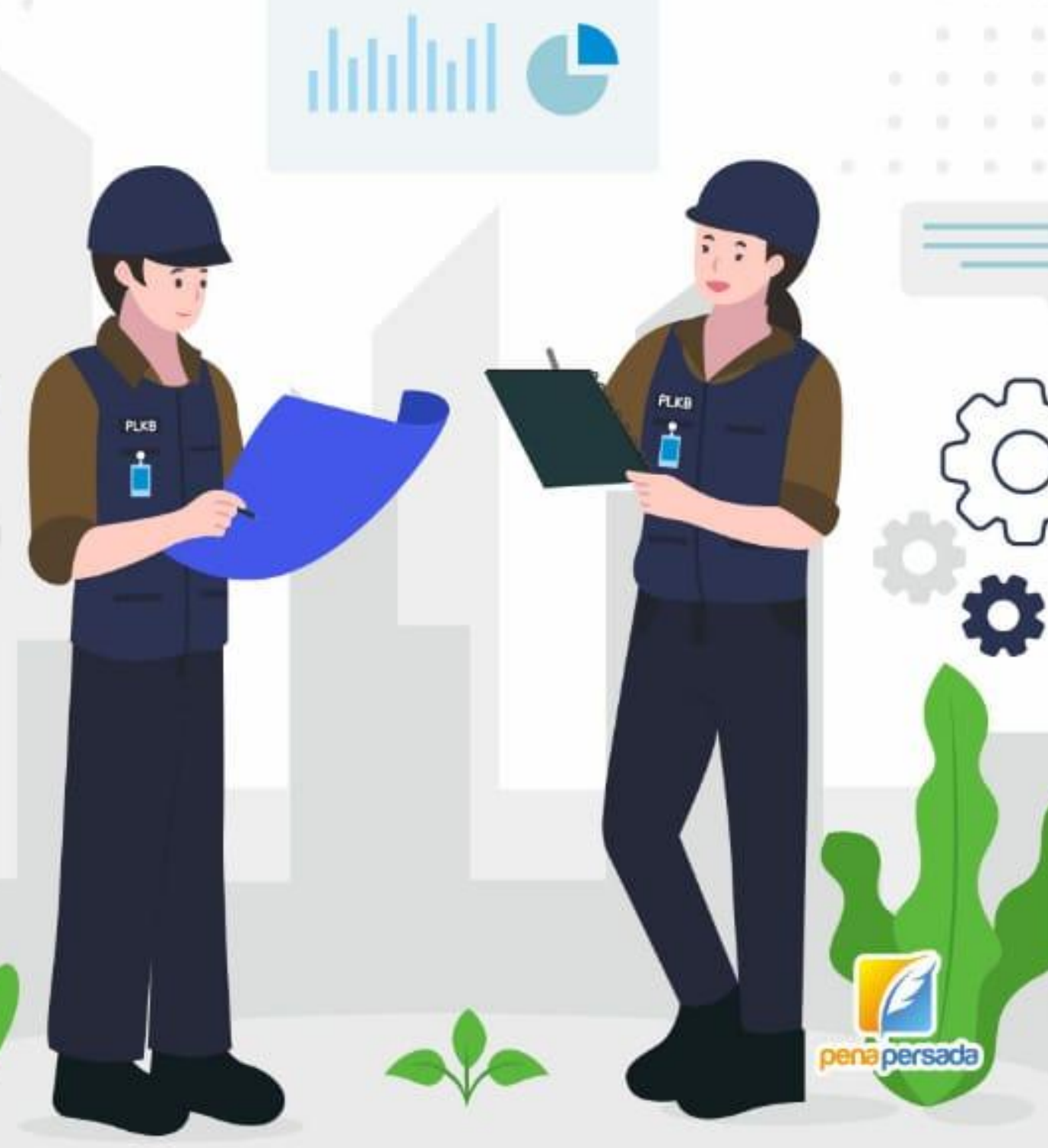
MODEL PENGEMBANGAN PETUGAS LAPANGAN KELUARGA BERENCANA

\author{
MAYA YUSNITA \\ DUWI AGUSTINA
}

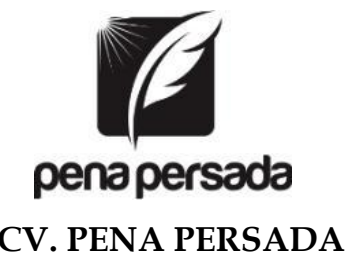




\title{
MODEL PENGEMBANGAN PETUGAS LAPANGAN \\ KELUARGA BERENCANA
}

\author{
Penulis :
}

Maya Yusnita

Duwi Agustina

ISBN : 978-623-6837-83-2

\section{Design Cover :}

Retnani Nur Briliant

\section{Layout :}

Hasnah Aulia

\section{Penerbit CV. Pena Persada \\ Redaksi :}

Jl. Gerilya No. 292 Purwokerto Selatan, Kab. Banyumas Jawa Tengah

Email : penerbit.penapersada@gmail.com

Website : penapersada.com

Phone : (0281) 7771388

Anggota IKAPI

All right reserved

Cetakan pertama : 2020

Hak cipta dilindungi oleh undang-undang.

Dilarang memperbanyak karya tulis ini dalam bentuk dan cara apapun tanpa ijin penerbit 


\section{KATA PENGANTAR}

Alhamdulillahhirobbil'alamin, puji syukur kami panjatkan ke-hadirat Allah SWT, karena atas ridho-Nya, buku ini dapat diselesaikan dengan baik. Buku ini disusun berdasarkan hasil penelitian yang berjudul "Mengukur Kinerja Pelayanan Petugas Lapangan Keluarga Berencana (PLKB) berbasis Customer Satisfaction melalui Pendekatan Importance Performance Analysis". Tujuan dari penelitian dan diterbitkannya buku ini adalah sederhana, yaitu untuk menganalisis kinerja pelayanan Petugas Lapangan Keluarga Berencana (PLKB) berbasis customer satisfaction pada masyarakat Kampung KB Kabupaten Bangka Tengah dan Kabupaten Bangka Barat Provinsi Kepulauan Bangka Belitung. Lebih lanjut, sasaran pembaca buku ini dapat digunakan oleh mahasiswa Fakultas Ekonomi di semua strata, para pemangku kebijakan, dan terutama bagi dosen sebagai buku ajar mata kuliah yang berhubungan dengan service quality.

Buku yang ada ditangan pembaca sekarang ini terdiri atas 6 BAB. BAB 1 berisi pendahuluan yang menjadi masalah utama tulisan ini, yaitu mengenai fenomena pelaksanaan

Petugas Lapangan Keluarga Berencana (PLKB) pada masyarakat Kampung KB Kabupaten Bangka Tengah dan Kabupaten Bangka Barat Provinsi Kepulauan Bangka Belitung. BAB 2 dijabarkan mengenai Kampung KB. BAB 3 mengenai Kinerja Petugas Lapangan Keluarga Berencana (PLKB). BAB 4 membahas mengenai Analisis Dan Strategi. BAB 5 mengenai Model Pengembangan PLKB, serta pada BAB 6 merupakan BAB terakhir yaitu penutup yang berupa simpulan dan rekomendasi yang dihasilkan.

Ucapan terima kasih dan penghargaan setingginya penulis sampaikan kepada Badan Kependudukan dan Keluarga Berencana Nasional (BKKBN) Provinsi Kepulauan Bangka Belitung, Universitas Bangka Belitung, serta semua pihak yang tidak dapat kami sebutkan satu persatu yang telah banyak membantu selama pelaksanaan penelitian dan sekaligus penerbitan buku ini. Terima kasih juga kami sampaikan kepada Lembaga Penelitian dan Pengabdian kepada Masyarakat (LPPM) Universitas Bangka 
Belitung yang telah memfasilitasi sehingga terlaksananya penelitian ini, serta ucapan terimakasih juga kami sampaikan kepada penerbit sehingga buku ini bisa ada dihadapan para pembaca. Demikian, semoga buku ini bermanfaat dan pembaca dapat memberikan masukan yang kritis dan konstruktif untuk perbaikan yang lebih baik.

Bangka Belitung, Oktober 2020

Penulis 
KATA PENGANTAR ........................................................... iii

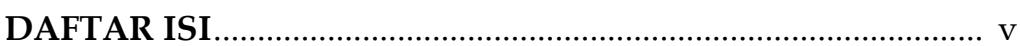

BAB 1 PENDAHULUAN ..................................................... 1

BAB 2 KAMPUNG KELUARGA BERENCANA `

A. Sejarah Kampung Keluarga Berencana (KB) ..................... 8

B. Definisi Kampung Keluarga Berencana (KB) .................... 10

C. Tujuan Kampung Keluarga Berencana (KB) ..................... 10

D. Sasaran Penggarapan Kampung Keluarga Berencana (KB) .............................................................. 11

E. Ruang Lingkup Kegiatan Kampung KB ......................... 12

\section{BAB 3 PENGUKURAN KINERJA PETUGAS}

\section{LAPANGAN KELUARGA BERENCANA}

A. Petugas Lapangan Keluarga Berencana (PLKB) ................ 13

B. Teori Customer Satisfaction ................................................. 19

\section{BAB 4 ANALISIS DAN STRATEGI}

A. Strategi IPA (Important Performance Analysis) ................... 22

B. Kinerja PLKB Kabupaten Bangka Tengah ......................... 25

C. Kinerja PLKB Kabupaten Bangka Barat ............................ 59

\section{BAB 5MODEL PENGEMBANGAN PLKB}

A. Model .................................................................................. 92

B. Rancangan Model Pengembangan PLKB ........................... 93

\section{BAB 6 PENUTUP}

A. Kesimpulan ......................................................................... 96

B. Saran .............................................................................. 96

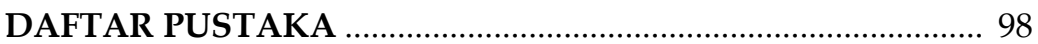

LAMPIRAN DOKUMENTASI PENELITIAN ........................ 102 


\section{MODEL PENGEMBANGAN PETUGAS}

LAPANGAN KELUARGA BERENCANA 


\section{BAB 1 \\ PENDAHULUAN}

Negara-negara berkembang selalu saja mengalami masalah utama yaitu pembangunan. Salah satu poin dalam masalah pembangunan yaitu berkenaan dengan masalah penduduk yang besar dengan kualitas hidup yang rendah (Normajatun, 2018). Penduduk merupakan sumber daya yang dimiliki oleh suatu bangsa. Penduduk yang produktif merupakan potensi atau aset pembangunan, sebaliknya penduduk yang bersifat non produktif dapat menjadi beban bagi pembangunan. Pertumbuhan penduduk bagi suatu negara dapat mempengaruhi perkembangan bangsa (Bachtiyar, 2017). Masih tingginya pertumbuhan penduduk serta kurang seimbangnya struktur umur penduduk di beberapa daerah di Indonesia menjadi masalah pokok yang dihadapi dalam bidang kependudukan dan keluarga berencana (Abdurrahman, 2019).

Sesuai dengan arah pembangunan pemerintahan periode 2015-2019, Badan Kependudukan dan Keluarga Berencana Nasional (BKKBN) merupakan salah satu Kementerian/Lembaga (K/L) yang diberi mandat untuk mewujudkan Agenda Pembangunan Nasional (Nawa Cita), terutama pada Cita ke-5 (lima) yaitu "Meningkatkan Kualitas Hidup Manusia Indonesia" melalui Pembangunan Bidang Pengendalian Penduduk dan Keluarga Berencana. Beberapa isu strategis dan permasalahan pengendalian kualitas penduduk, sebagaimana tertuang di dalam RPJMN 2015-2019 yang harus mendapat perhatian khusus adalah: (1) Peningkatan Akses dan Kualitas Pelayanan KB yang merata untuk dapat mengatasi permasalahan pelayanan KB; (2) Penguatan Advokasi dan Komunikasi, Informasi dan Edukasi (KIE) tentang Program Kependudukan, Keluarga Berencana, dan Pembangunan Keluarga (KKBPK); (3) Peningkatan pemahaman dan kesadaran remaja mengenai kesehatan reproduksi dan penyiapan kehidupan berkeluarga; (4) Pembangunan keluarga melalui peningkatan pemahaman dan kesadaran fungsi keluarga; 
(5) Penguatan landasan hukum dalam rangka optimalisasi pelaksanaan pembangunan bidang Kependudukan dan Keluarga Berencana (KKB); (6) Penguatan data dan informasi kependudukan (Renstra BKKBN Tahun 2015-2019).

Potensi yang dapat dikembangkan oleh BKKBN melalui program atau kegiatan direktif Presiden adalah "Kampung KB". Kampung KB merupakan salah satu potensi utama yang dapat memperkuat implementasi Program KKBPK dilini lapangan serta dapat menjadi jembatan integrasi kegiatan antara BKKBN dengan lintas Kementerian/Lembaga dan lintas sektor (Pemerintah Pusat dengan Pemerintah Daerah Provinsi dan Kabupaten/Kota) (Renstra BKKBN Tahun 2015-2019). Melalui Kampung KB, diharapkan pelaksanaan Program KKPBK dan program-program pembangunan lainnya dapat berjalan secara terpadu dan bersama. Secara umum, tujuan dibentuknya Kampung KB adalah untuk meningkatkan kualitas hidup masyarakat ditingkat kampung atau yang setara melalui program KKBPK serta pembangunan sektor lainnya dalam rangka mewujudkan keluarga kecil berkualitas. Secara khusus, Kampung KB dibentuk untuk meningkatkan peran serta pemerintah, lembaga non-pemerintah dan swasta dalam memfasilitiasi, mendampingi, dan membina masyarakat untuk menyelenggarakan program KKBPK dan pembangunan sektor terkait, serta untuk meningkatkan kesadaran masyarakat tentang pembangunan berwawasan kependudukan (bkkbn.go.id).

Pemerintah Provinsi Kepulauan Bangka Belitung menargetkan hingga tahun 2022 mendatang, Provinsi Kepulauan Bangka Belitung memiliki 90\% Kampung KB dari 391 desa atau kelurahan. Berikut disajikan rekapitulasi perkembangan Kampung KB di Provinsi Kepulauan Bangka Belitung Tahun 2016-2018. 
Tabel 1.1

Rekapitulasi Perkembangan Kampung KB

Tahun 2016-2018

\begin{tabular}{|c|c|c|}
\hline Kabupaten/Kota & Tahun & Jumlah Kampung KB \\
\hline \multirow[t]{4}{*}{ Belitung } & 2016 & 1 \\
\hline & 2017 & 5 \\
\hline & 2018 & 5 \\
\hline & Total & 11 \\
\hline \multirow[t]{4}{*}{ Bangka } & 2016 & 1 \\
\hline & 2017 & 8 \\
\hline & 2018 & 8 \\
\hline & Total & 17 \\
\hline \multirow[t]{4}{*}{ Pangkalpinang } & 2016 & 1 \\
\hline & 2017 & 7 \\
\hline & 2018 & 4 \\
\hline & Total & 12 \\
\hline \multirow[t]{4}{*}{ Bangka Tengah } & 2016 & 1 \\
\hline & 2017 & 6 \\
\hline & 2018 & 4 \\
\hline & Total & 11 \\
\hline \multirow[t]{4}{*}{ Bangka Selatan } & 2016 & 1 \\
\hline & 2017 & 8 \\
\hline & 2018 & 8 \\
\hline & Total & 17 \\
\hline \multirow[t]{4}{*}{ Belitung Timur } & 2016 & 1 \\
\hline & 2017 & 7 \\
\hline & 2018 & 7 \\
\hline & Total & 15 \\
\hline \multirow[t]{4}{*}{ Bangka Barat } & 2016 & 1 \\
\hline & 2017 & 6 \\
\hline & 2018 & 8 \\
\hline & Total & 15 \\
\hline
\end{tabular}

Sumber: babel.bkkbn.go.id, 2020 
Berdasarkan Tabel 1.1 diatas, dapat diketahui bahwa secara umum perkembangan Kampung KB di Provinsi Kepulauan Bangka Belitung terus mengalami peningkatan yang cukup signifikan dalam kurun waktu 3 tahun terakhir.

\section{Tabel 1.2.}

Rekapitulasi Kampung KB

Kabupaten Bangka Tengah

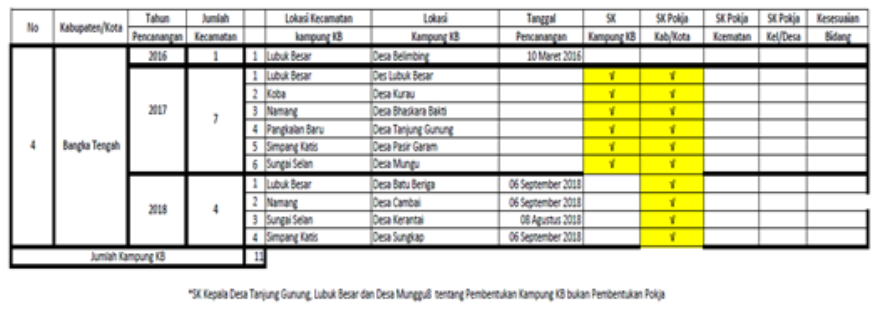

Sumber: babel.bkkbn.go.id, 2020

Berdasarkan Tabel 1.2 diatas, dapat diketahui bahwa pada Tahun 2018, perkembangan Kampung KB pada Kabupaten Bangka Tengah mengalami penurunan sebesar $5 \%$ dengan lokus (desa) yang berbeda pada tahun sebelumnya.

\section{Tabel 1.3.}

Rekapitulasi Kampung KB

Kabupaten Bangka Barat

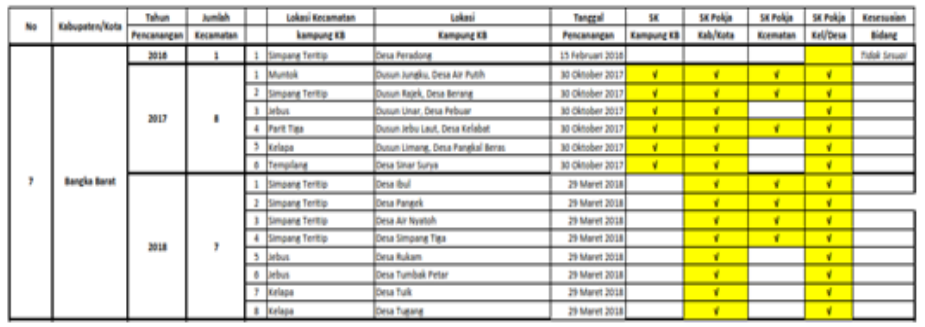

Sumber: babel.bkkbn.go.id, 2020 
Berdasarkan Tabel 1.3 diatas, dapat diketahui bahwa pada Tahun 2018, perkembangan Kampung KB pada Kabupaten Bangka Barat secara umum mengalami peningkatan dari tahun sebelumnya. Namun, jika dilihat dari jumlah kecamatan yang ada, maka terjadi penurunan jumlah Kampung KB.

\section{Grafik 1.1}

Trend Pencapaian Peserta KB Baru

Provinsi Kepulauan Bangka Belitung Tahun 2018

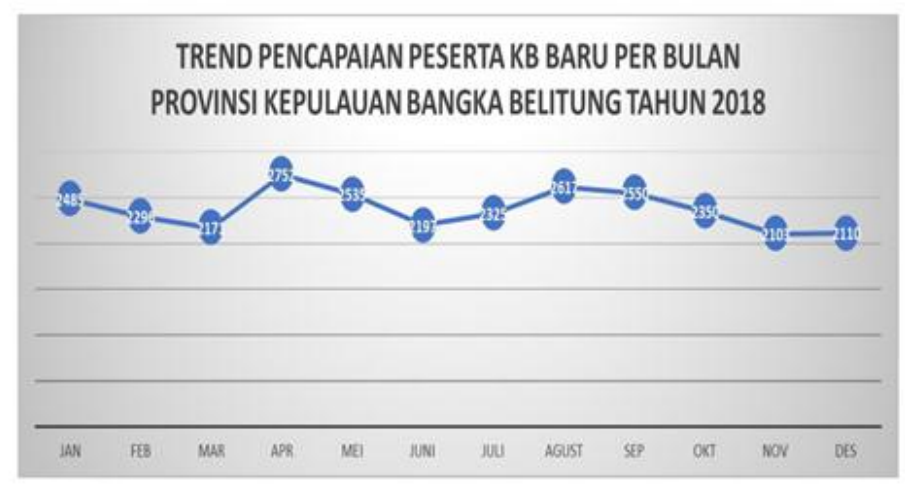

Sumber: babel.bkkbn.go.id, 2020

Berdasarkan grafik 1.1 di atas, dapat diketahui bahwa trend pencapaian peserta KB baru per bulan pada Provinsi Kepulauan Bangka Belitung cenderung mengalami penurunan yang cukup signifikan khususnya dimulai dari bulan Agustus hingga November 2018. Pada bulan Desember mengalami kenaikan pencapaian, namun tidak signifikan, yaitu sebesar $0,3 \%$. 


\section{Grafik 1.2.}

Trend Pencapaian Peserta KB Baru

Kabupaten Bangka Tengah Tahun 2018

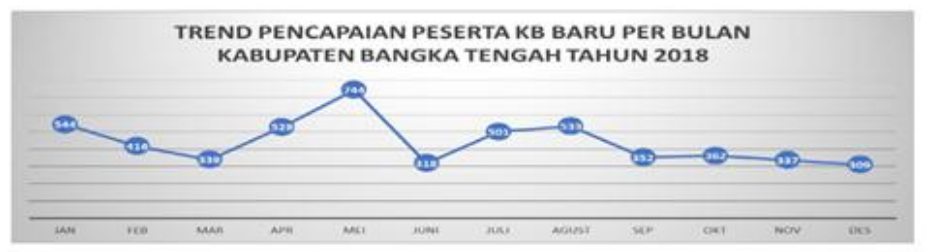

Sumber: babel.bkkbn.go.id, 2020

Berdasarkan grafik 1.2 di atas, dapat diketahui bahwa trend pencapaian peserta KB baru per bulan pada Kabupaten Bangka Tengah mengalami penurunan cukup tajam khususnya pada 2 bulan terakhir, yaitu November dan Desember dengan persentase masing-masing sebesar 7,41\% dan 9,06\%.

\section{Grafik 1.3.}

Trend Pencapaian Peserta KB Baru

Kabupaten Bangka Barat Tahun 2018

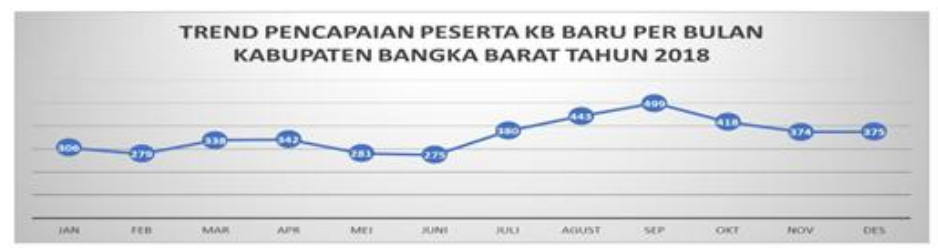

Sumber: babel.bkkbn.go.id, 2020

Berdasarkan grafik 1.3 di atas, dapat diketahui bahwa trend pencapaian peserta KB baru per bulan pada Kabupaten Bangka Barat mengalami penurunan yang cukup signifikan khususnya dari bulan September ke November 2018 dengan persentase masing-masing sebesar 16,23\% dan 10,52\%.

Penyuluh KB/Petugas Lapangan KB merupakan "ujung tombak" dalam Program KKBPK yang dihandalkan untuk dapat 
meningkatkan kualitas hidup masyarakat Indonesia. Penyuluh KB/Petugas Lapangan KB (PLKB) merupakan pelopor penerapan 8 Fungsi Keluarga dan revolusi mental melalui Keluarga. Penyuluh KKBPK merupakan sumber daya yang potensial serta dibutuhkan oleh masyarakat untuk memberikan informasi dan edukasi terkait pentingnya program KKBPK.

Kepuasan menurut Oliver, seperti yang dikutip oleh J. Supranto (1997), kepuasan merupakan tingkat perasaan seseorang setelah membandingkan kinerja atau hasil yang dirasakannya dengan harapannya. Sehingga, tingkat kepuasan merupakan fungsi dari perbedaan antara kinerja yang dirasakan dengan harapan. Pada dasarnya pengertian kepuasan pelanggan mencakup perbedaan antara tingkat kepentingan dan kinerja atau hasil yang dirasakan (Syukri, 2014).

Petugas Lapangan Keluarga Berencana (PLKB) terdiri dari PLKB dengan status Pegawai Negeri Sipil (PNS) dan Non Pegawai Negeri Sipil (PNS). Namun, model pengembangan PLKB pada kajian ini difokuskan kepada PLKB dengan status Non PNS. Hal ini dikarenakan berdasarkan wawancara dengan pihak BKKBN Provinsi Kepulauan Bangka Belitung, diperoleh beberapa informasi diantaranya: (1) PLKB Non PNS saat ini berada dibawah naungan masing-masing Kabupaten/Kota yang ada di Provinsi Kepulauan Bangka Belitung, sehingga tidak terdapat keseragaman dalam pedoman pelaksanaan yang memuat aturan rekrutmen hingga evaluasi PLKB; (2) Kewenangan pengelolaan PLKB Non PNS sepenuhnya dipegang oleh masing-masing Pemerintah Kabupaten/Kota, sehingga tidak terdapat koordinasi dengan pihak BKKBN Provinsi Kepulauan Bangka Belitung; serta (3) Pelaporan kinerja PLKB Non PNS masih dilakukan secara manual, yaitu dengan mengisi laporan kegiatan. Hal ini berbeda dengan PLKB dengan status PNS yang telah menggunakan aplikasi khusus dalam pelaporan kinerja (E-Visum). 


\section{BAB 2 \\ KAMPUNG KELUARGA \\ BERENCANA (KB)}

\section{A. Sejarah Kampung Keluarga Berencana (KB)}

Kampung KB merupakan wujud dari pelaksanaan agenda prioritas pembangunan Nawacita ke 3, 5, dan 8 . Nawacita ketiga yaitu membangun Indonesia dari pinggiran dengan memperkuat daerah-daerah dan desa dalam kerangka negara kesatuan. Nawacita kelima yaitu meningkatkan kualitas hidup masyarakat serta Nawacita kedelapan yaitu melakukan revolusi karakter bangsa melalui kebijakan penataan kembali kurikulum pendidikan nasional dengan mengedepankan aspek pendidikan kewarganegaraan, yang menempatkan secara proporsional aspek pendidikan, seperti pengajaran sejarah pembentukan bangsa, nilai-nilai patriotisme dan cinta Tanah Air, semangat bela negara dan budi pekerti di dalam kurikulum pendidikan Indonesia.

Kampung KB menjadi program inovatif yang strategis dalam mengejawantahkan program KKBPK secara paripurna di lapangan. Pasalnya, Kampung KB menjadi model atau miniatur pembangunan yang melibatkan seluruh sektor di masyarakat. Kampung KB adalah miniatur pelaksanaan program KB secara terpadu dan komprehensif ditingkat lini lapangan (desa/kelurahan/dusun/RW).

Konsep kampung KB merupakan konsep terpadu program $K B$ dengan program pembangunan lainnya seperti pendidikan, kesehatan, ekonomi. Kampung KB ini didesain sebagai upaya pemberdayaan masyarakat terhadap pengelolaan program KB. Kegiatannya dikelola berdasarkan prinsip dari, oleh dan untuk masyarakat itu sendiri. Penetapan wilayah kampung KB sesuai kriteria utama yakni jumlah PraKS dan KS-1 (miskin) diatas rata-rata Pra-KS dan KS-1, jumlah peserta KB belum cukup tinggi, kriteria wilayah termasuk wilayah yang padat penduduk serta kriteria program KB 
seperti peserta KB aktif dan penggunaan metode kontrasepsi jangka panjang, rendah dengan tingkat Unmet Need tinggi. Program KB ini berupaya mewujudkan keluarga sejahtera yang berkualitas.

Partisipasi berbagai instansi dalam kampung KB sangat penting sehingga pelayanan paripurna dapat dirasakan langsung oleh masyarakat menuju kesejahteraan masyarakat. Berbagai kegiatan yang dilaksanakan di kampung KB diantaranya optimalisasi pengasuhan dan pembinaan tumbuh kembang anak sejak dikandungan sampai seribu hari pertama kehidupan, perencanaan kehamilan yang baik sejak pra nikah dan selama mengandung, menurunkan angka fertilitas melalui pelayanan KB yang bermutu merata dan dapat diakses oleh seluruh keluarga serta mengembangkan kualitas keluarga melalui Bina Keluarga Balita (BKB). Pelaksanaan Kampung KB perlu didukung oleh lintas sektor karena dalam pelaksanaan peningkatan kualitas keluarga tidak hanya BKKBN yang mengampu, namun seluruh sektor masyarakat perlu bergerak maju bersama.

Kampung KB menjadi salah satu wadah strategis dalam upaya menyelaraskan program-program lintas sektor lainnya seperti Program 1000 Hari Pertama Kehidupan Rumah Sehat, Genre (Generasi Berencana) dan Gerakan Masyarakat Sehat. Melalui berbagai program dan kegiatan itu, diharapkan masyarakat di Kampung KB memperoleh pembinaan yang berkelanjutan di dalam membangun keluarga kecil, bahagia, dan sejahtera.

Sejak dicanangkan oleh Presiden Joko Widodo pada tanggal 14 Januari 2016, Kampung KB terus tumbuh pesat. Dimulai pada tahun 2016 itulah Kampung KB telah dan sedang diselenggarakan di setiap kabupaten dan kota Bupati, dan Walikota di seluruh Indonesia. Kampung KB dibentuk dengan melibatkan tokoh masyarakat, tokoh agama, dan masyarakat di dengan bimbingan, pembinaan, dan fasilitasi baik dari pemerintah pusat maupun pemerintah daerahnya. 
Kampung KB merupakan salah satu 'senjata pamungkas' baru pemerintah dalam mengatasi masalah kependudukan, terutama di wilayah-wilayah yang jarang 'terlihat' oleh pandangan pemerintah. Kampung KB kedepannya akan menjadi ikon program kependudukan, KB dan Pembangunan Keluarga (KKBPK). Kehadiran Kampung KB bertujuan meningkatkan kualitas hidup masyarakat ditingkat kampung atau yang setara melalui program KKBPK serta pembangunan sektor lain dalam rangka mewujudkan keluarga kecil berkualitas.

\section{B. Definisi Kampung Keluarga Berencana (KB)}

Menurut BKKBN (2015), Kampung Keluarga Berencana (KB) adalah satuan wilayah setingkat RW, dusun atau setara yang memiliki kriteria tertentu, dimana terdapat keterpaduan program kependudukan, keluarga berencana, pembangunan keluarga dan pembangunan sektor terkait yang dilaksanakan secara sistemik dan sistematis.

\section{Tujuan Kampung Keluarga Berencana (KB)}

Secara umum tujuan dibentuknya kampung KB adalah untuk meningkatkan kualitas hidup masyarakat ditingkat kampung atau yang setara melalui program KKBPK serta pembangunan sektor terkait lainnya dalam rangka mewujudkan keluarga kecil berkualitas.

Secara khusus kampung KB bertujuan untuk meningkatkan peran Pemerintah, Pemerintah Daerah, Lembaga non Pemerintah dan swasta dalam memfasilitasi, melakukan pendampingan dan pembinaan kepada masyarakat agar turut berperan serta aktif dalam meningkatkan kualitas hidup masyarakat melalui:

1. Peningkatan kualitas dan akurasi data dan peta keluarga

2. Peningkatan jumlah Peserta KB Aktif (CU/PUS)

3. Peningkatan jumlah Peserta KB MKJP

4. Peningkatan jumlah Peserta KB Pria

5. Penurunan angka unmet need 
6. Peningkatan Partisipasi keluarga yang memiliki balita dalam Bina Keluarga Balita (BKB)

7. Peningkatan Partisipasi keluarga yang memiliki remaja dalam BKR

8. Peningkatan Partisipasi keluarga yang memiliki lansia dalam BKL

9. Peningkatan Partisipasi lansia dalam BKL

10. Peningkatan Partisipasi remaja dalam PIK

11. Peningkatan Rata-rata usia kawin pertama perempuan

12. Peningkatan Pemberdayaan perempuan dan perlindungan anak

13. Peningkatan gizi dan kesehatan masyarakat

14. Peningkatan status sosial ekonomi

15. Peningkatan rata-rata lama sekolah anak usia sekolah

16. Peningkatan lingkungan dan pemukiman yang sehat

17. Peningkatan kualitas pembangunan sektor pembangunan terkait

\section{Sasaran Penggarapan Kampung Keluarga Berencana (KB)}

Sasaran:

Sasaran yang merupakan subjek dan objek dalam pelaksanaan program dan kegiatan di Kampung KB adalah:

1. Keluarga;

2. Remaja;

3. Penduduk Lanjut Usia (Lansia);

4. Pasangan Usia Subur (PUS);

5. Keluarga dengan balita;

6. Keluarga dengan remaja;

7. Keluarga dengan lansia;

8. Sasaran sektor sesuai dengan bidang tugas masing masing.

\section{Pelaksana:}

1. Kepala Desa/Lurah;

2. Ketua RW;

3. Ketua RT;

4. PKB/PLKB/TPD;

5. Petugas Lapangan sektor terkait; 
6. Pembinaan Kesejahteraan Keluarga (PKK) Tingkat Desa/Kelurahan;

7. Institusi Masyarakat Pedesaan (PPKBD dan Sub PPKBD)

8. Tokoh Masyarakat (Tokoh Adat/Tokoh Agama/Tokoh masyarakat di desa/kelurahan);

9. Kader.

\section{E. Ruang Lingkup Kegiatan Kampung KB}

Ruang lingkup pelaksanaan kegiatan di Kampung KB meliputi:

1. Kependudukan;

2. Keluarga Berencana dan Kesehatan Reproduksi;

3. Ketahanan Keluarga dan Pemberdayaan Keluarga (Pembangunan Keluarga);

4. Kegiatan Lintas Sektor (Bidang Pemukiman, Sosial Ekonomi, Kesehatan, Pendidikan, Pemberdayaan Perempuan dan Perlindungan Anak dan sebagainyadisesuaikan dengan kebutuhan wilayah Kampung KB). 


\section{BAB 3 \\ PENGUKURAN KINERJA PETUGAS \\ LAPANGAN KELUARGA \\ BERENCANA (PLKB)}

\section{A. Petugas Lapangan Keluarga Berencana (PLKB)}

\section{Definisi}

PLKB adalah Pegawai Negeri Sipil atau non Pegawai Negeri Sipil yang diangkat oleh pejabat yang berwenang yang mempunyai tugas, tanggung jawab untuk melaksanakan kegiatan penyuluhan, pelayanan, evaluasi dan pengembangan KKB. PLKB/PKB adalah Pegawai Pemerintah Daerah (Pemda) Kabupaten/Kota berkedudukan di Desa/Kelurahan yang bertugas melaksanakan atau mengelola, menggerakkan, member-dayakan serta menggalang dan mengembangkan kemitraan dengan berbagai pihak dalam pelaksanaan program KB bersama institusi masyarakat pedesaan/perkotaan ditingkat Desa/Kelurahan.

2. Fungsi dan Tugas Petugas Lapangan Keluarga Berencana (PLKB)

\section{Fungsi PLKB}

PLKB/PKB mempunyai fungsi merencanakan, mengorganisasikan, mengembangkan, melaporkan dan mengevaluasi program KB Nasional dan Program pembangunan lainnya ditingkat Desa/Kelurahan.

\section{Tugas PLKB}

PLKB memiliki beberapa tugas, meliputi:

a. Melakukan konsolidasi dengan semua pihak terkait untuk menyusun rencana pelaksanaan kegiatan program KB Nasional ditingkat lini lapangan.

b. Mengumpulkan dan mengolah data mengenai aspekaspek demografis, sosial budaya, geografis, tingkat peran serta masyarakat dan IMP sebagai bahan analisis dan evaluasi di tingkat desa. 